\title{
Light, photosynthetic capacity and growth of papaya (Carica papaya L.): a short review
}

\author{
Jefferson R. Silva ${ }^{1}$, Weverton P. Rodrigues ${ }^{1}$, Katherine Fraga Ruas ${ }^{1}$, Jessica Sousa Paixão ${ }^{1}$, Roberta Samara \\ Nunes de Lima ${ }^{2}$, José Altino Machado Filho ${ }^{3}$, Juan Alberto Cabrera Garcia ${ }^{4}$, Bruce Schaffer ${ }^{5}$, Julian Cuevas \\ Gonzalez $^{6}$, Eliemar Campostrini* ${ }^{1}$
}

\author{
${ }^{1}$ Setor Fisiologia Vegetal, Centro de Ciências e Tecnologias Agropecuárias, Ecofisiologia de Culturas Tropicais e \\ Subtropicais, Univ. Estadual Norte Fluminense (UENF), Darcy Ribeiro, 28013-602, RJ, Brazil \\ ${ }^{2}$ Universidade Federal de Alagoas, CRAD - UFAL - Campus Arapiraca, Rod. AL 115 Km 6,5 - Arapiraca - AL, Cx. Postal: \\ 61 - CEP: $57300-970$ \\ ${ }^{3}$ Instituto Capixaba de Pesquisa, Assistência Técnica e Extensão Rural. Vitória, ES, 29052-010 Brazil \\ ${ }^{4}$ Instituto Canario de Investigaciones Agrarias (ICIA) - Universidad de La Laguna (ULL). Santa Cruz de Tenerife, Spain \\ ${ }^{5}$ Tropical Research and Education Center, University of Florida, 18905 SW 280 Street, Homestead, FL 33031-3314, \\ Homestead, USA \\ ${ }^{6}$ Escuela Superior de Ingeniería Campus de Excelencia Agroalimentaria (ceiA3), Universidad de Almeria, Carretera de \\ Sacramento s/n, Almeria, Spain
}

*Corresponding author: camposternator@gmail.com

\begin{abstract}
Papaya (Carica papaya L.) is one of the main horticultural crops of many tropical and subtropical regions. The fruit is sold either as a fresh product or processed into drinks, jams, candies, dried and crystallized fruit, while the enzyme papain is used for medicinal purposes. Papaya fruits have high vitamins A and C contents, as well as are good sources of calcium. Brazil is one of the most important producers and exporters of papaya in the world; in 2016 c.a., 1,424,650 tons of papaya was produced in 30,372 hectares of the territory. Optimum light absorption and utilization by the canopy are important factors for maximizing papaya crop growth and productivity. Thus, knowing how papaya responds to light is important to develop management strategies to optimize fruit yield and quality. This short review aims to present the current research knowledge related to the effects of light intensity on the photosynthetic processes and growth of papaya. We demonstrate that photosynthetically active radiation (PAR) greatly affects the physiology of papaya. Understanding the interaction between light and physiological processes is extremely important for a sustainable profitable production under either greenhouse or field conditions. By using improved light science-based management, growers may optimize photosynthetic carbon assimilation and increase papaya yield and fruit quality.
\end{abstract}

Key words: abiotic factors; protected papaya plantations; chlorophyll fluorescence, photosynthesis; water relations.

Introduction

In 2016, $63.10 \%$ of the world's total papaya (Carica papaya L.) production was concentrated in three countries, India $(133,000$ ha and $5.699,000$ ton), Brazil $(30,372$ ha and $1,424,650$ ton) and Nigeria (97,838 and 951,922 ton) (FAOSTAT, 2016). In terms of productivity, the Dominican Republic, Costa Rica, Indonesia, Belize, Mexico, Brazil and China had the highest production with 287.8, 90.9, 90.6, $60.2,56.6,46.9$ and 19.6 ton of fruit ha $^{-1}$, respectively.

Papaya is an important fruit crop of tropical and subtropical regions grown not only for its fruit, but also as a source of papain, a commercially valuable proteolytic enzyme that is produced in the milky latex of green, unripe fruit (Dunne and Horgan, 1992). Evolutionarily, papain may be associated with protection from frugivorous predators and herbivores (El Moussaoui et al., 2001). Papaya fruit is known for its high content of vitamins A and C, and is a good source of calcium.
On an average, $100 \mathrm{~g}$ of ripe papaya contains 950 I.U. of Vitamin A and $60.9 \mathrm{mg}$ of vitamin C (ascorbic acid) (USDA, 2017). The peel of the fruit is green when unripe and orange when ripe (Ali and Lazan, 1998). The soft reddish orange pulp has a distinct sweet flavor with a slight musk tang. Ripe papaya fruits are normally consumed as dessert (Ali and Lazan, 1998). Green fruits, leaves and flowers can also be used as cooked vegetables (Watson, 1997).

Although the exact center of origin is unknown, it is believed that papaya is native to tropical America, perhaps in Southern Mexico and neighboring Central America (Morton, 1987). The center of diversification of papaya was the lowlands of Central America and Southern México, and possibly West Indies (Caribbean) (Crane, 2005). It has been reported that seeds were taken to Panama and then to the Dominican Republic before the year 1525 and the cultivation 
spread to warm elevations of South and Central America, Southern Mexico, the West Indies and Bahamas, and as far as Bermuda in 1616 (Morton, 1987). Papaya was taken to the Caribbean and Southeast Asia first and then spread to India, Oceania, and Africa (Crane, 2005).

Papaya plants may reach $9 \mathrm{~m}$ height (Campostrini et al., 2010). Thus, papaya is considered a giant herb (Malo and Campbell, 1986). However, the stem is semi-woody since lignin accumulation in the cell wall is at an intermediate level between Arabidopsis and poplar (Ming et al., 2008). Similar to poplar, the increased number of genes associated to cell expansion in papaya is consistent with larger plants' and is related to lignin biosynthesis showing a convergent evolution of a tree-like habit (Ming et al., 2008).

Papaya plants have a rapid growth rate and usually a shortlife ( 2 to 3 years), but can produce fruit for more than 20 years (Malo and Campbell, 1986). Papaya is typically singlestemmed, although branching can occur with age or if the apex is removed (Marler et al, 1994). Cultivated papaya trees in Brazil are usually replaced before exceeding 3-4 $\mathrm{m}$ in height. Hollow petioles up to $1 \mathrm{~m}$ long bear simple leaves with deep lobes. Leaves may be up to $70 \mathrm{~cm}$ in diameter (Marler et al., 1994).

The papaya has a complicated reproductive system (Marler et al., 1994). Plants are either male, hermaphrodite, or female. Flowers grow either singly (female and hermaphrodite plants) or in large clusters (male) in leaf axils (Marler et al., 1994). Plants can produce flower and fruits continuously after flowering initiation and leaves generally senesce and abscise before fruits are harvested (Zhou et al., 2000).

Commercial papaya cultivation is restricted to tropical and subtropical areas due to chilling damage at temperatures above freezing (Yadava et al., 1990). However, there is growing interest in this crop for cooler areas, such as Spain, Israel, Argentina, Australia and Japan. For instance, papaya has been grown outdoors in the Southern republics of the former Soviet Union (Kapanadze and Khasaya, 1988) and as an annual crop in the Southeastern United States (Yadava et al, 1990). Over 350 ha are cultivated in the Canary Islands (ISTAC, 2017), where the crop is mostly (90\%) planted in greenhouses (Figure 1), covered either by mesh or polyethylene film to prevent the infection of papaya plants with the ring spot virus (PRSV), as well as to benefit plants with controlled climatic conditions that are required to produce good quality fruits (Galán Saúco and Farré Massip, 2006; Galán Saúco and Rodríguez Pastor, 2007) and high annual yields in a range of $200 \mathrm{t} \mathrm{ha}^{-1}$ in a 22 months cycle (Julian Cuevas Gonzalez, personal communication). Commercial plantings of papaya in Australia occur throughout coastal tropical and subtropical regions of New South Wales, Queensland and Western Australia, with Queensland accounting for $>95 \%$ of production (Garret, 1995).

The study of light effects on photosynthetic carbon assimilation is important because papaya cultivation is increasing under protected structures, such as at plantations located in the Canary Islands and in Southern Spain, as well as in Turkey (Gunes and Gubbuk, 2012; Campostrini et al., 2018), Israel, and Japan (Galán and Pastor, 2007). Thus, it is important to construct protective structures that could allow better light distribution within the canopies in order to optimize photosynthesis and improve plant growth and yield. In sites where protected structures are used for papaya production, attacks by aphids which transmit PRSV are better controlled. Additionally, protected cultivation reduces damages by wind, hail and excess solar radiation. Yet, water use is decreased in protected structures since evapotranspiration is reduced by c.a. $25 \%$. Fruit yield and quality have also been observed to increase when papaya is grown under protected structures (Galán and Pastor, 2007). Another important aspect of knowing the optimum quantities of light for optimal physiological functioning of papaya is that plant spacing can be adjusted for maximum light distribution within the canopy. Maximum light interception is obtained with very large plant spacing (and training and pruning that is not the case for papaya). On the other hand, leaving optimum light availability to very few plants leads to poor yields (although of high quality). The trend in orchard design is the contrary, so that many trees are planted although light interception is not good. Different tools have been used to improve light absorption. The aim is to reach a good correlation between number of plants and optimum radiation absorption by papaya leaves. Since maximum profits are desirable, the ideal plant density is the one that provides maximum yields per unit of area.

Moreover, light management strategies such as painting the greenhouse structure in white, covering the soil with white mulching plastic, whitening the roof of greenhouses, removing the oldest leaves, and applying whitewash (processed kaolinite clay) to leaf surfaces, can be implemented to increase light absorption by the canopy (Glenn et al., 2005; Glenn and Puterka, 2010; Sharma et al., 2015). Thus, the challenge for papaya production will be to increase high quality fruit production in current planted areas and marginal sites where climatic conditions are limiting. The aim of this short review is to show the state of art related to light effects on both photosynthetic capacity and growth of papaya plant.

\section{Importance of light to papaya plants}

The term "light" is often defined as the electromagnetic radiation perceived by the human eye (wavelength: 380-760 $\mathrm{nm})$. However, in the field of physics, it refers to a wider range of electromagnetic radiation ranging from ultraviolet $(10-380 \mathrm{~nm}$ ) to infrared (760 nm-1 m) (Fujiwara and Kozai, 1995) (Figure 2). The photosynthetic reactions of plants are driven by light at wavelengths between 400 and $700 \mathrm{~nm}$, known as photosynthetic active radiation (PAR, $\mu \mathrm{mol}$ photons $\mathrm{m}^{-2} \mathrm{~s}^{-1}$ ) (Fujiwara and Kozai, 1995). In this short review, the term "light" (PAR) is defined as the electromagnetic radiation which causes photochemical reactions in plants.

Papaya is a light-demanding plant and prolonged low light intensity can cause significant alterations in the leaf anatomy and morphology (Buisson and Lee, 1993). Buisson and Lee (1993) studied the effects of light intensity and light quality on morphology and growth of papaya. In one treatment, they reduced light intensity by $70 \%$ (using screens) and in another treatment. They also sharply reduced the Red/far Red ratio (R/fR). Compared to plants cultivated in full sunlight, these treatments caused reductions in leaf thickness, specific leaf weight, stomatal 


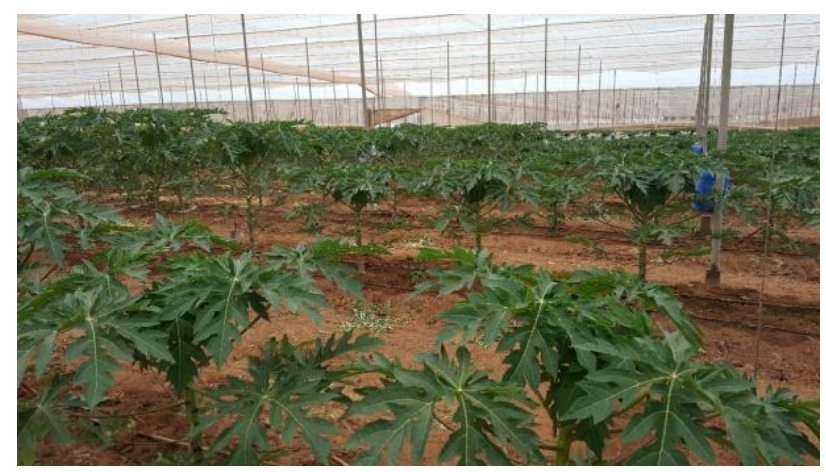

Fig 1. Commercial scale protected papaya plantations in the Canary Islands.

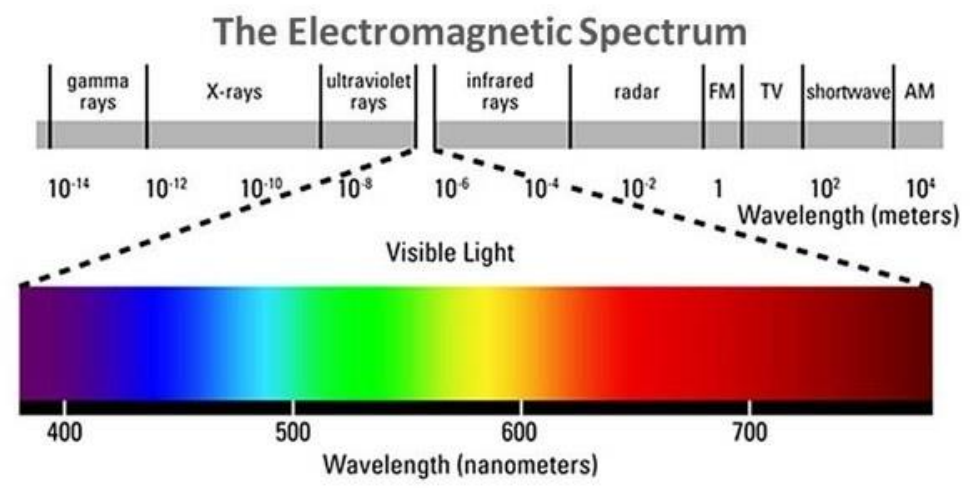

Fig 2. Electromagnetic spectrum. The visible portion of the electromagnetic spectrum is just a tiny portion of the full spectrum.

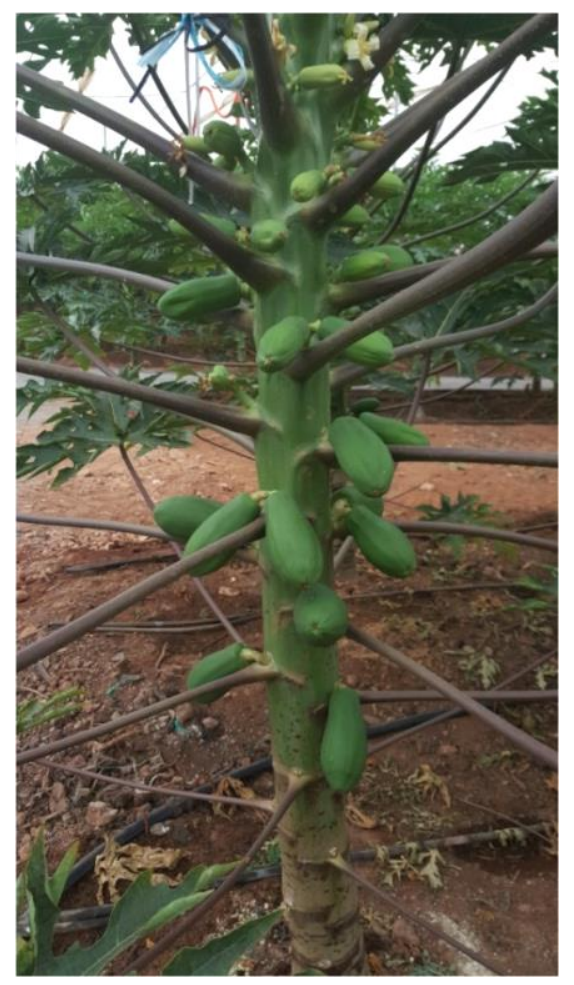

Fig 3. 3:8 spiraled phyllotaxis configuration of the papaya leaves. There are three leaves positioned clockwise or counterclockwise within each 360 degrees turn around the trunk. 
density, leaf area and petiole length, as well as increased chlorophyll content per unit leaf area and the amount of air space into the leaf mesophyll. The reduction in light intensity also greatly reduced the number of lobules on the leaf. The presence of more lobules in leaves of papaya grown in full sunlight compared to those in $70 \%$ shade may be associated with an increased amount of leaf surface in contact with the air, which increases leaf cooling.

The light saturation point [the light intensity where net photosynthetic rate $\left(P_{n}\right)$ reaches its maximum] of papaya leaves is dependent on plant age and growth conditions. For example, in individual leaves formed in full sunlight $\left(13^{\text {th }}\right.$ to $14^{\text {th }}$ leaf below the apex) and conditions of adequate water and nutrient availability, photosynthetic carbon assimilation in six-month-old plants is saturated at around $2000 \mu \mathrm{mol}$ photons $\mathrm{m}^{-2} \mathrm{~s}^{-1}$ (Marler and Mickelbart, 1998). However, in young papaya (three-month-old) leaves grown under full sunlight at $1250 \mu \mathrm{mol}$ photons $\mathrm{m}^{-2} \mathrm{~s}^{-1}$ maximum light intensity, the light saturation point is lower, at c.a. 1100 $\mu \mathrm{mol}$ photons $\mathrm{m}^{-2} \mathrm{~s}^{-1}$ (Marler et al., 1993). In four-month-old plants grown in a greenhouse, at $1200 \mu \mathrm{mol}$ photons $\mathrm{m}^{-2} \mathrm{~s}^{-1}$ maximum light intensity with adequate water supply and $V P D_{\text {air }}$ of about $1 \mathrm{kPa}$, light saturation of the mature leaf $\left(10^{\text {th }}\right.$ leaf below the apex) was $1000 \mu \mathrm{mol}$ photons $\mathrm{m}^{-2} \mathrm{~s}^{-1}$ (Peçanha, 2010).

Reduced light intensity can cause a significant decrease in photosynthetic carbon assimilation in papaya (Marler and Mickelbart, 1998; Peçanha, 2010; Wang et al., 2014). Although PAR is very important for photosynthesis, excess light energy can also decrease carbon assimilation by the leaf. When the light source is solar radiation, this decrease in the $P_{n}$ under excessive radiation conditions is caused by the interaction of stomatal and non-stomatal factors. High solar radiation can cause leaf heating, increase the vapor pressure deficit between the leaf surface and surrounding air $\left(\mathrm{VPD}_{\text {leaf- }}\right.$ air) and promote stomatal closing, reducing $\mathrm{CO}_{2}$ entry into the leaf mesophyll, thus diminishing the concentration of $\mathrm{CO}_{2}$ at the Rubisco carboxylation sites. Non-stomatal effects associated with lower photosynthetic carbon assimilation under excess solar radiation are due, in part, to photoinhibition, whereby photosystem II (PSII) is damaged (Vass, 2012; Goh et al., 2012). This destruction sharply reduces photochemical efficiency, with damage to ATP and NADPH synthesis (Vass, 2012). An interaction between supra-optimal leaf temperatures and photochemical efficiency can also be observed, because temperatures above 44 으 increase the initial fluorescence emission by excited chlorophyll $a$ in the antennae structure of the PS II $\left(F_{0}\right)$, thus reducing the photochemical efficiency (Weng and Lai 2005).

Wang et al. (2014) reported that the leaves located on the lower part of papaya canopy cultivated under protected system (35th to 45th leaf below the apex) received only c.a $20 \%$ of the solar radiation that reached leaves in the upper portion of the canopy ( $13^{\text {th }}$ to $20^{\text {th }}$ leaf below the apex). Thus, in protected structures, removing leaves located in the lower part of the canopy can reduce the number of sinks in the plants and reduce transpiration, thereby lowering plant water uptake and allocating transpiration and mineral nutrient to the upper leaves in the canopy. These upper leaves have a higher $P_{n}$, because they receive a greater amount of light. To effectively implement these light maximization strategies in protected systems, it is necessary to determine the effects of light intensity on the photosynthetic process.

Knowledge of the optimum light intensities for maximum photosynthetic efficiency of papaya provides a basis for reducing excess solar energy in field plantations. When adequate light intensities are known, actions such as applying particle films to the leaves (Glenn and Puterka, 2010; Sharma et al., 2015), to prevent light damage to the photochemical apparatus and increased leaf temperature, can be implemented to provide adjustments to the quantity of solar radiation absorbed by the leaf lamina. Excess light energy can be considerably more harmful to the photochemical apparatus of water-stressed papaya plants than to well-watered plants. In papaya plants grown with low water availability (soil water tension of $-68 \mathrm{kPa}$ ), the light saturation point was significantly decreased, showing that under field conditions, the optimal light intensity can also be altered by the amount of water in the soil (Marler and Mickelbart, 1998). If water availability is limited, particle films are more effective at protecting leaves from photochemical damage, because such particles increase excess light energy reflection in locations where there is intense solar radiation (Glenn and Puterka, 2010; Sharma et al., 2015).

In addition to the light saturation point for optimum $P_{n}$ being an important consideration, other variables related to light intensity such as the light compensation point (the light intensity at which $P_{n}$ is 0 ) and a quantum yield (defined as the molar amount of $\mathrm{O}_{2}$ evolved or $\mathrm{CO}_{2}$ absorbed per mol of photons absorbed by the photosynthetic apparatus) are important for papaya production. In mature leaves (13th and 14th leaf below the apex) of six-months-old papaya plants grown in the field without water limitation, the light compensation point was 27,29 and $30 \mu \mathrm{mol}$ photons $\mathrm{m}^{-2} \mathrm{~s}^{-1}$ for papaya cultivars 'Tainung 2', 'Red Lady' and 'Sunrise', respectively (Marler and Mickelbart, 1998). Under such condition, the values of incident quantum yield $\left(\Phi_{\mathrm{i}}\right)$ were $0.039,0.041$ and $0.040 \mu \mathrm{mol} \mathrm{CO}_{2} \mu \mathrm{mol}$ photons leaf ${ }^{-1}$, respectively for each cultivar. In 103-days-old 'Golden' papaya plants grown in a greenhouse when soil water was not limited and maximum PAR was $1000 \mu \mathrm{mol}$ photons $\mathrm{m}^{-2} \mathrm{~s}$ ${ }^{1}, \Phi_{\mathrm{i}}\left(\mathrm{CO}_{2}\right.$ assimilation for each photon unit that reaches the papaya leaf lamina was $0.034 \mu \mathrm{mol} \mathrm{CO}_{2} \mu \mathrm{mol}_{\text {photons }}{ }^{-1}$ leaf $^{-1}$ (Lima, 2014). In leaves of $C_{3}$ plants, including papaya, without water limitation the mean $\Phi_{i}$ was $0.053 \mu \mathrm{mol} \mathrm{CO}_{2}$ $\mu$ mol photons ${ }^{-1}$ (Björkman and Demming, 1987). In the leaves of two papaya varieties (UENF Caliman 01 and Golden) ( $6^{\text {th }}$ leaf below the apex) cultivated in a greenhouse with adequate water, the compensation irradiance (Ic; the minimum light intensity limit on the leaf lamina where photosynthetic carbon assimilation is positive,) was 100 $\mu \mathrm{mol}$ photons $\mathrm{m}^{-2} \mathrm{~s}^{-1}$ (Peçanha, 2010). At light intensities below this Ic value, the $\mathrm{CO}_{2}$ release rate (respiration) is higher than $\mathrm{CO}_{2}$ assimilation (photosynthesis). The $\Phi_{\mathrm{i}}$ and Ic values are extremely important in protected cultivations, because knowing these values can be important in choosing planting spacing, greenhouse design for protected cultivation and in canopy management strategies, i.e., removal of very shaded leaves located in the lower part of the canopy, as reported previously (Wang et al., 2014). In leaves at different positions within the canopy of different papaya cultivars, high Ic values indicate more sensitivity of a particular cultivar to shading. 
Knowledge of the $\Phi_{i}$ values for optimal papaya plant growth is important because cultivars that have high $\Phi_{i}$ value have a higher $\mathrm{CO}_{2}$ assimilation rate in environments where the light intensity (PAR) is high. This is important in tropical regions where papaya is cultivated. In these regions, there is a higher predominance of clouds, which can cause intense fluctuations in light energy absorbed by the leaf lamina (Way and Pearcy, 2012). Normally, high $\Phi_{i}$ values are associated with lower Ic values. This is important for breeding programs since genetically improved papaya cultivars with high $\Phi_{i}$, and low Ic values.

The stomata of papaya are very sensitive to fluctuations in light intensity (Clemente and Marler, 1996), which is strongly reflected in the $\Phi_{i}$ values. When light intensity is reduced quickly, the stomata close at a rate of $3 \mathrm{mmol} \mathrm{m}^{-2} \mathrm{~s}^{-}$ ${ }^{1}$ (Clemente and Marler, 1996), which is a very high stomata closing rate. This value was obtained when papaya leaves receiving $2000 \mu \mathrm{mol}$ photons $\mathrm{m}^{-2} \mathrm{~s}^{-1}$ were suddenly exposed to a reduced light intensity of $300 \mu \mathrm{mol}$ photons $\mathrm{m}^{-2} \mathrm{~s}^{-1}$. This shows the sensitivity of this species to shading which is very important when growing papaya under protected cultivation, because in these environments light can be limited by the type of structure and the plastic cover used. An important consideration is that water shortage in the soil can raise the rate at which the stomata close when the intensity of light impacting the papaya leaf lamina is reduced (Clemente and Marler 1996).

\section{Light interception effects on papaya physiology}

Plant spacing can significantly influence light interception by crop plants, affects the impact of weed competition and alters morphophysiological characteristics of the plants with significant effects on final crop yield and quality. Light interception by crop canopies is determined by planting density, planting pattern, and morphological characteristics of the component species (Loomis and Connor, 1992). Full coverage is achieved most rapidly when: 1) population density is high, 2) seedlings partition a significant proportion of new assimilates to leaf development, 3) specific leaf weight is small, and 4) leaf angle is low. The interception of radiation and early productivity are then maximal and the crop is also able to shade out shorter weed competitors. Highly productive canopies have the characteristics of full cover and erect leaves, at least at the top of the canopy (Loomis and Connor, 1992). However, in papaya plant the spiral leaf insertion on the trunk, associated with a long petiole, allows efficient light distribution in the papaya canopy (Ferraz et al., 2016) (Figure 3).

In India, different spacing are being adopted in different traits for different papaya cultivars (Reddy, 1995). For example, with 'Coorg Honey Dew' papaya, maximum fruits plant $^{-1}$ and fruit yield plant ${ }^{-1}$ were obtained with 2267 plants $\mathrm{ha}^{-1}$ and the minimum with 3703 plants $\mathrm{ha}^{-1}$. A plant population of 4629 plants ha $^{-1}$ produced the maximum fruit yield ha ${ }^{-1}$, whereas 2267 plants ha $^{-1}$ produced the minimum. An increasing plant density reduced the average fruit weight. The benefit/cost ratio was maximum (2.44:1) with 2267 plants $\mathrm{ha}^{-1}$, and minimum (1.67:1) with 4444 plants ha${ }^{1}$. Plant height and girth were non-significantly different among different plant densities (Reddy, 1995). Santos et al. (2016) found double spacing $(3.8 \times 2.0 \times 1.8 \mathrm{~m})$ promoted greater interception of PAR and increased PAR-use efficiency compared to single spacing $(3.8 \times 2.0 \mathrm{~m})$. At the same time, fruit yield in double spaced plants was higher than in single spaced plants, showing that under double spacing, papaya plants intercepted more PAR with higher efficiency.

\section{Concluding remarks}

Light, as discussed in the present short review, can control photosynthetic processes and affect papaya plant growth. Thus, regardless of whether papaya is grown under either field or protected cultivation, understanding this important environmental factor on photosynthetic carbon assimilation is extremely important for commercial papaya production. Finally, information included in this review could greatly aid in future papaya breeding efforts, as well as could facilitate agricultural site selection for future papaya cultivation.

\section{Acknowledgements}

The authors would like to thank Coordination for University Personnel Training (Coordenação de Aperfeiçoamento de Pessoal de Nível Superior (CAPES), National Council for Scientific and Technological Development (CNPq) (fellowship 300996/2016-0 to E. Campostrini), Foundation for Research Support of Rio de Janeiro state (Fundação de Amparo à Pesquisa do Estado do Rio de Janeiro (FAPERJ)), and Study and Projects Financier [Financiadora de Estudos e Projetos (FINEP)] for financial support of the research.

\section{References}

Ali M, Lazan H (1998) Papaya. In: Shaw PE, Chan HJ, Jr Nagy S (eds.) Tropical and Subtropical Fruits, Agscience Inc Florida USA. 4.

Buisson D, Lee DW (1993) The development responses of papaya leaves to simulated canopy shade. Am J Bot. 80:947952.

Björkman O, Demming B (1987) Photon yield of $\mathrm{O}_{2}$ evolution and chlorophyll fluorescence characteristics at 77K among vascular plants of diverse origins. Planta. 170:489-504.

Campostrini E, Glenn DM, Yamanishi OK (2010) Papaya: ecophysiology of growth and production. In: DaMatta, F. (Ed.) Ecophysiology of tropical tree crops. Nova Science Publishers, New York, USA. 20.

Campostrini E, Schaffer B, Ramalho JD, González JC; Rodrigues WP; da Silva JR; Lima, RS (2018) Environmental factors controlling carbono assimillation, growth, and yield of papaya (Carica papaya L.) under water-scarcity scenarios. In: Tejero IFG, Zuazo VHD (eds) Water scarcity and sustainable agriculture in semiarid environment. Academic Press, London, UK. 24.

Clemente HS, Marler TE (1996) Drought stress influences gasexchange responses of papaya leaves to rapid changes in irradiance. J Am Soc Hortic Sci. 12:292-295.

Crane JH (2005) Papaya growing in the Florida Home Landscape. University of Florida. IFAS Extension Publication. 8.

Dunne J, Horgan L (1992) Meat tenderizers. In: Hui, YH (ed) Encyclopedia of Food Science and Technology. $3^{\text {rd }}$ edition, Wiley, New York. USA. 6

El Moussaoui A, Nijs M, Paul C, Wintjens R, Vincentelli J, Azarkan $M$, Looze $Y$ (2001) Revisiting the enzymes stored in the laticifers of Carica papaya in the context of their possible participation in the plant defense mechanism. Cell Mol Life Sci. 58:556-570.

FAOSTAT (2014) FAO data for agriculture: statistics database: http://faostat.fao.org/ 
faostat/collections?version=extandhasbulk=0andsubset=agric ul-ture (Accessed on April 01, 2017).

Ferraz TM, Rodrigues WP, Torres Netto A, Reis FO, Peçanha AL, Figueiredo FAMMA, Sousa EF, Glenn DM, Campostrini E (2016) Comparison between single-leaf and whole-canopy gas exchange measurements in papaya (Carica papaya L.) plants. Sci Hortic-Amsterdam. 209:73-78.

Food and Nutrition Board, Institute of Medicine, National Academies

(2017). https://www.ncbi.nlm.nih.gov/books/NBK56068/table/summ arytables.t2/?report=objectonly

Fujiwara K, Kozai T (1995) Physical microenvironment and its effects. In: Aitken-Christie J, Kozai T, Smith MAL (eds) Automation and Environmental Control in Plant Tissue Culture. Kluwer Academic Publishers, Dordrecht, Netherlands. 50.

Garret A (1995) The pollination biology of papaw (Carica papaya L.) in Central Queeensland. PhD Thesis, Central Queensland University, Rockhampton, Australia.

Galán Saúco VG, Farré Massip JMF (2006) Tropical and subtropical fruit production in Spain. Chronica Hortic. 46:26-30.

Galán Saúco VG, Rodríguez Pastor MCR (2007) Greenhouse cultivation of papaya. Acta Hortic. 740:191-195.

Goh CH, Ko SM, Koh S, Kim YJ, Bae HJ (2012) Photosynthesis and environments: photoinhibition and repair mechanisms in plants. J Plant Biol. 55:101-2012.

Glenn DM, Drake S, Abbott JA, Puterka GJ, Gundrum P (2005) Season and cultivar influence the fruit quality response of apple cultivars to particle film treatments. HortTechnology 15:249253.

Glenn DM, Puterka GJ (2010) Particle Films: A New Technology for Agriculture. Hortic Rev. 31:1-24.

Gunes E, Gubbuk H (2012) Growth, yield and fruit quality of three papaya cultivars grown under protected cultivation. Fruits. 67:23-29.

ISTAC (2017) Instituto canario de estadística. http://www.gobiernodecanarias.org/istac/ (Accessed on April 01, 2017).

Kapanadze I, Khasaya GS (1988) Some characteristics of pawpaw trees. Subtropicheskie Kul'tury. 1:136-140.

Lima RSN (2014) Irrigação parcial do sistema radicular e déficit de irrigação regulado em mamoeiro (Carica papaya L.): capacidade fotossintética, crescimento e eficiência no uso da água. PhD Thesis, UENF, Campos dos Goytacazes, RJ, Brazil.

Loomis RS, Connor DJ (1992) Crop ecology: productivity and management in agricultural systems. Cambridge University Press, Cambridge, England, 538 pp.

Malo SE, Campbell CW (1986) The papaya. Gainesville: University of Florida, Cooperative Extension Service Fruits Crops Fact Sheet FC-11.

Marler TE, George AP, Nissen RJ, Andersen PC (1994) Miscellaneous tropical fruits. In: Schaffer B, Andersen PC (eds). Handbook of environmental physiology of fruits crops. Volume II, Subtropical and tropical crops., CRC Press, Florida, USA. 30.

Marler TE, Mickelbart MV (1998) Drought, leaf gas exchange, and chlorophyll fluorescence of field grown papaya. J Am Soc Hortic Sci. 23:714-718.

Marler TE, Mickelbart MV, Quitugua R (1993) Papaya Ringspot Virus Influences Net Gas Exchange of Papaya Leaves. HortScience. 28:322-324.
Ming R, Hou S, Feng Y, Yu Q, Dionne-Laporte A, Saw JH, Senin P, Wang W, Ly BV, Lewis KLT, Salzberg SL, Feng L, Psii MR, Skelton RL, Murray JE, Chen C, Qian W, Shen J, Du P, Eustice $\mathrm{M}$, Tong $\mathrm{E}$, Tang $\mathrm{H}$, Lyons $\mathrm{E}$, Paull RE, Michael TP, Wall K, Rice DW, Albert H, Wang ML, Zhu YJ, Schatz M, Nagarajan N, Acob RA, Guan P, Blas A, Wai CM, Ackerman CM, Ren Y, Liu C, Wang J, Wang J, Na JK, Shakirov EV, Haas B, Thimmapuram J, Nelson $D$, Wang $X$, Bowers JE, Gschwend AR, Delcher AL, Singh R, Suzuki JY, Tripathi S, Neupane K, Wei H, Irikura B, Paidi M, Jiang $N$, Zhang $W$, Presting $G$, Windsor $A$, Navajas-Perez $R$, Torre MJ, Feltus FA, Porter B, Li Y, Burroughs AM, Luo MC, Liu L, Christopher DA, Mount SM, Moore PH, Sugimura T, Jiang, J, Schuler MA, Friedman V, Mitchell-Olds T, Shippen DE, De Pamphilis CW, Palmer, JD, Freeling M, Paterson AH, Gonsalves D, Wang L, Alam M (2008) The draft genome of the transgenic tropical fruit tree papaya (Carica papaya Linnaeus). Nature. 452:991-997.

Morton J (1987) Fruits of warm climates. Creative Resource Systems, Miami, Florida, USA. 10.

Peçanha AL (2010) Metabolismo fotossintético, crescimento e estado nutricional do mamoeiro (Carica papaya L.) em resposta à condutividade elétrica da solução de cultivo. PhD Thesis, UENF, Campos dos Goytacazes, RJ, Brazil.

Reddy YTN (1995) Effect of plant spacing on "Coorg Honey Dew" papaya (Carica papaya). Indian J Agr Sci. 65:130-132.

Santos EM, Júnior S, Cavalcante ÍHL, Marques AS, Albano FG (2016) Planting spacing and NK fertilizing on physiological indexes and fruit production of papaya under semiarid climate. Bragantia. 75:63-69.

Sharma RR, Vijay Rakesh Reddy S, Datta SC (2015) Particle films and their applications in horticultural crops. Appl Clay Sci. 116:54-68.

USDA

https://ndb.nal.usda.gov/ndb/foods/show/2305?manu=\&fgcd $=\& d s$

Vass I (2012) Molecular mechanisms of photodamage in the photosystem II complex. Biochim Biophys Acta. 1817:209217.

Wang, RH, Chang, JC, Li, KT, Chang, LS (2014) Leaf age and light intensity affect gas exchange parameters and photosynthesis within the developing canopy of field net-house-grown papaya trees. Sci Hortic-Amsterdam. 165:365-373.

Way DA, Pearcy RW (2012) Sunflecks in trees and forests: from photosynthetic physiology to global change biology. Tree Physiol. 32:1066-1081.

Weng J, Lai M (2005) Estimating heat tolerance among plant species by two chlorophyll fluorescence parameters. Photosynthetica. 43:439-444.

Watson B (1997) Agronomy/agroclimatoly notes for the production of papaya. MAFFA, Australia.

Yadava UL, Burris AJ, McCrary D (1990) Papaya: a potential annual crop under middle Georgia conditions. In: Janick, J., J.E. Simon (Eds.), Advances in New Crops. Timber Press, Oregon, USA, 2.

Zhou L, Christopher DA, Paull R (2000) Defoliation and fruit removal effects on papaya fruit production, sugar accumulation, and sucrose metabolism. J Am Soc Hortic Sci. 125:644-652. 